\title{
A KOLOZSVÁRI JEZSUITA EGYETEM SZER VEZETE ÉS ÉPÍTKEZÉSEI A XVIII. SZÁZADBAN
}

\author{
IRTA \\ BIRÓ VENGEL
}

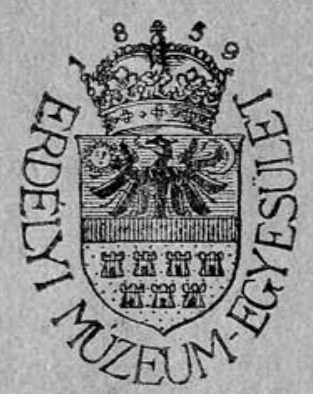

KOLOZSYAR, 1945

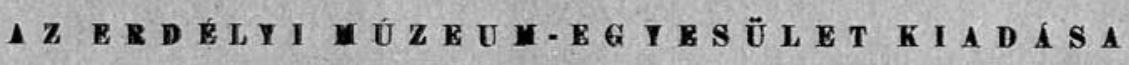




\title{
ER DÉLY I T UDOM Á NYOS FÜZETEK
}

\section{A KOLOZSVÁRI JEZSUITA EGYETEM SZERVEZETE ÉS ÉPITTKEZÉSEI A XVIII. SZÁZADBAN}

\author{
IRTA \\ BIRÓ VENCEL
}

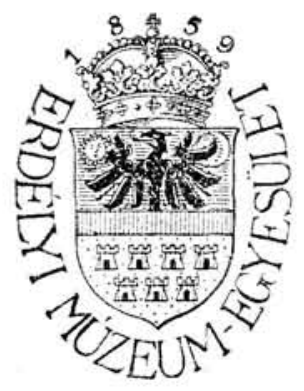

K OL OZSYAR, 1945

A Z E R D ÉLY I M ÜZ E U M-E G Y E S ÜL E T K I A D A S A 
Különlenyomat

az ERDÉLYI MÚZEUM

1945. évi 1-2. füzetéböl
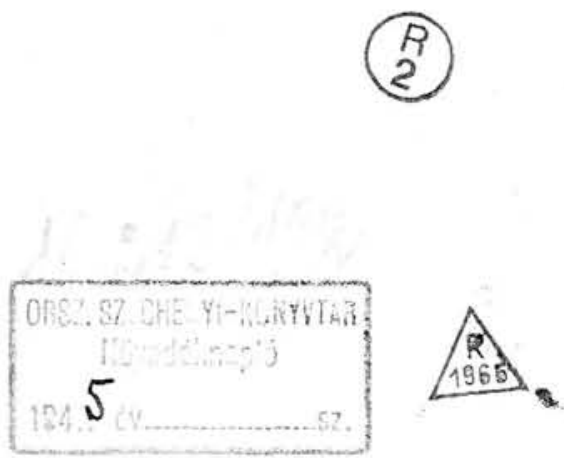

Felelös kiadó: Dr. Szabó T. Attila

Minerva Nyomdai Müintézet R.-t., Kolozsvár. 7109. - Felelös vezetō: Kiss M. ig. 
1.

Erdélynek föiskola-szervezö fejedelmei szándékuk megvalósításában egyúton haladtak. Akár János Zsigmondot, Báthory Istvánt, Bethlen Gábort, akár a Rákócziakat nézzuik, egyetértettek abban, hogy az országnak egyetemre szüksége van, és hogy annak tanári karát a legjobb erőkböl kell összeállítani. A hazai tanulás szükségességét legvilágosabban Báthory István fejezte ki a kolozsvári egyetem alapitólevelében. Ó olasz egyetemen tanult és így tudta, hogy köitségesség tekintetében mit jelent a külföldön tanulás. Szegénysége miatt a külföldi tanulás hiányában mennyi tehetség kallódik el felhasználatlanul. Ugyanezt érezte át Bethlen Gábor is, amikor legalább itthon alkalmat kívánt adni a tanulásra.

Tisztában voltak mindannyian azzal, hogy az egyetem tekintélyét elsősorban tanárainak arravalósága adja meg, azért a tanári kar összeállításában, a hazai tanárok mellett külföldiek alkalmazását is számításba vették. A nemzetközi latin nyelv használata és az egyetemek meglehetősen hasonló szervezete miatt, szándékuk végrehajtása nagyobb nehézségekbe nem ütközött. János Zsigmond megbizottat küldött ki jeles külföldi tanárok behívására. Bethlen is, majd a Rákócziak is több külföldi tanárt nyertek meg főiskolájuk számára. Báthory István meg az akkor virágzó jezsuita rendet bízta meg a töle alapított kolozsvári egyetem ellátásával. Mindegyik fejedelem iskolaalapítását saját egyháza keretébe illesztette be. A közoktatás ugyanis akkor a vallások hivatása volt. Az uralkodók szervezéssel és gazdag alapítványokkal támogatták az iskolát. A föiskolák kapui azonban bármely vallású és bármely nemzethez tartozó tanuló számára nyitva állottak. Az egyházak tehát országos feladatot oldottak meg.

Báthory Istvántól alapított jezsuita egyetem tanárai között voltak erdéiyi magyarok, akáresak a többi fejedelem főiskoláján. Az ö egyeteme sem távolodott el az erdélyi gondolkozástól, söt a vitatkozásra feltett kérdések, egy-egy elöadott színdarab és a hazai viszonyokhoz való alkalmazkodás tanúsága szerint e gondolkozásba egyre jobban beleilleszkedtek. A fejedelem és vele együtt az ország minden vallású rendei a jezsuitákban képzett tanárokat láttak, ennek megfelelöleg tőlük sokat vártak. Bíztak abban, hogy nem kísérleteznek, hanem más országokban alkalmazott tanítási rendjükkel lépnek be Erdély föıdjére.

E tanítási rendszer pedig az akkori idők kívánalmait kielégítette. $\mathrm{Az}$ egyetem szoros kapesolatban állott a gimnáziummal, söt a gimnázium mint nyelvi fakultás (facultas linguarum) az egyetemnek egyik 
karát alkotta. A tulajdonképeni egyetem böleseleti és teológiai karra oszlott. A bölcseleti tanulmányok két évig tartottak. Az elsó évfolyam tárgyai: a logika, metafizika, a második télévben ezekhez járult még a matematika. A második évben fizikát (kinematika, dinamika, kozmográfia, hötan, fénytan, cseppfolyós testek sztatikája) tanulták, a második félévben etikát is. Betetözésül a teológia következett, melynek tanulmányozása négy évet vett igénybe. Tárgyai voltak: dogmatika (I-IV.), szentírás-magyarázat (I-IV.), kánonjog (III-IV.), hitvitázás (I-II.), továbbá egyháztörténelem, ékesszólástan, héber és görög nyelv. A theologia moralis és a kazuisztika tanítása nem minden főiskolán ment egyöntetúen. ${ }^{1}$

Báthory István alapítólevele és a vitatkozásra tett kérdések tanúsága szerint az ő egyeteme is böleseleti és teológiai karral indult. Az egyetemi fokot bizonyította, hogy a föiskola egyetemi fokozatokat (borostyánkoszorús, magister, doctor) osztogatott. Az alapítólevél 1581-ben kelt. ${ }^{2}$ Ez évben már benn a városban kezdödött a tanítás, addig, 1579 ôta, künn, Kolozsmonostoron müködött a föiskola.

A jezsuiták 1588-ban történt kiutasításuk után, esak megszakításokkal folytathatták tanítói munkájukat. Tevékenységük nagyobbarányú kibontakozása csak a fejedelemség megszünése után következett be. Most kezdődő munkásságuk 1773-ig tartott, alkotásuk azonban ez idön túl is századokon keresztuil megmaradt.

A fejedelemség után beállott új, helyzetben, a Habsburg uralkodók meg a katolikus társadalom pártfogása és visszanyert vagyona révén a rend nagyobb munkalehetőséghez jutott. Ekkor nemesak középiskolákat nyitott, vagy a meglévöket jobban felszerelte, hanem a föiskolai oktatăst is megkezdette. Gr. Apor István erdélyi kinestartó 8000 forint alapítványával lehetövé tette, hogy 1698 óta a böleseletet is tanították.

A XVIII. században újraéledt föiskola kezdetben Collegium Academicum, akadémiai kollégium nevet viselt. Élén állott az akadémiai rektor (rector academicus), neve 1725-től rector magnificus. Segítöje a cancellarius, amely hivatalt többször egyben maga a rektor töltötte be. A kancellár feladata abban állott, hogy a tanulmányok menetére és rendjére ügyeljen. Tulajdonképen ö voit az akadémia igazgatója. Az 1720-as években a kolozsvári akadémián a rektor egyben kancellár is volt, utóbb a két tisztséget két kézben találjuk. ${ }^{3}$

A karok számát 1703-tól kísérhetjük figyelemmel. Ez évvel kezdődőleg két egykorú értékes forrás kínálkozik, amelyek a föiskola szervezetére felvilágosítást adnak. Egyik magának a főiskolának Névkönyve. ${ }^{4}$

${ }^{1}$ Fináczy Ernő, A magyarországi közoktatás története Mária Teréża korában. I, 98-102.

${ }^{2}$ Veress Endre, Font. Rer. Trans. I, 91-92, 127-132.

${ }^{3-4}$ A kollégium 1703-tól 1772-ig terjedő kéziratos Névtárából vett adatok. Ebbe Dávid Pál a következő megjegyzést tette: „Notandum: pro distractione a tolleratio után ezzen könyv kezemhez került, és nékem adatott, által attam Minorita P. Béla Andrásnak mint jó emberemnek, kiis ottan ottan szép jedzékeket tett. két testvéreiröl s egyebekről is. Nagy káris az, midőn holmi nevezetes történt dolgokat fel nem jegyez az ember jövendö- 
E könýv magában foglalja a rektornak, kancellárnak, a jezsuita tanároknak nevét évröl-évre a tanulók névsorával együtt. A tanulók nevét karok szerint tünteti fel. A másik egykorú forrás a jezsuita diákotthonban (convictus) lakó tanulók névsora 1703-tól kezdve osztályaik, vagy vagyonukhoz mért ellátásuk (I-II-III. asztal) szerint. $^{5}$ Kiegészito" adatokkal szolgál még a jezsuita rendház története az 1701. évvel kezdődöleg 1747-ig. ${ }^{6}$ A folytatólagos kötet lappang. ${ }^{7}$

E forrásokból megállapítható, hogy a föiskola csak a böleseleti karral kezdödött, hittudományi tanulók 1712-től szerepelnek. A bölesészeti kar első évfolyamának hallgatói a főtantárgyról elnevezve logikus-ok, a második év hallgatói meg fizikusok. A teológiai hallgatók kevés számuk miatt (4-5-7) nem alkottak külön kart, a theologia moralist azonban 1712-1726 között tanították. Az ilyenek a theologia scolastica tanulására Nagyszombatba mentek. A hittanhallgatók érdekében a metafizika tanítását közben annyira elmélyítették, hogy ennek hallgatói a bölesészeti karban harmadik évfolyam gyazánt jönnek elö. A tárgyat inkább a teológusok tanulták, világi hallgató elvétve fordult elö. İgy ez évfolyam a teológia első évének is tekinthető. A bölesészeti kar elsỏ és második évfolyamának hallgatói átlag világiak voltak néhány hittanhallgatóval vegyítve.

A hallgatók rangsora e szerint alulról fölfelé számítva: logikus, fizikus metafizikus, theologus moralis. A konviktusi bejegyzés gyakran casistá-t (casus-eset-ből), azaz hitvitázót említ. Számokat illetőleg néhány adat: 1711-ben logikus 11, fizikus 7. 1712-ben theologus moralis 4. fiziko-metafizikus 7, logikus 16, 1726-ban theologus moralis 7. metafizikus 8 , fizikus 11 , logikus 18. 1738-ban metafizikus 15 , fizikus 15 , logikus 31. 1750-ben metafizikus 14, fizikus 20. Az utóbbi években az évfolyamokat kettőre vonták össze.

Ả hallgatók többnyire magyarok voltak, föleg székelyek, állandóan találunk azonban más nemzetbelieket is. Feltünö, hogy a fönemes-ifjak milyen szép számmal látogatták a föiskolát. Közülök többen kiszolgáló

belieknek olvasására, mivel midőn ollyan régiséghez akadhat az olvasó, kiből valamit tanul, vagy pediglen közben halgatván mások régiségekről mit szóllanak, tehát fontosabban tud hozzá szollani. Ebben magomat vádolhatom, hogy eleitöl fogva ottan történt nevezetes dolgokat nem jegyeztem fel magamnak." - E Névtár Dávid Páltól 1791-ben fiához, Dávid János nagyenyedi kántor- és orgonistához került, ö pedig 1811-ben Br. Toroezkay Józsefnek adta át. A kézirat a Toroczkay család levéltárával a budapesti Országos Levéltárba került. Címe hiányzik, lapszámozás nines. A könyv vastagsága 4-5 $\mathrm{cm}$, börkötéses, ívrétü, a végéröl a be nem írt lapok hiányoznak. L. a marosvásárhelyi letéti osztályon őrzött Toroczkay levelek 79. csomóját.

${ }^{5}$ Liber continens nomina et historias convictorum Claudiopoli anno 1703 (Kézirat a kolozsvári piarista rendházban).

${ }^{\circ}$ Historia S. J. Claudiopoli ab anno millesimo septingentesimo primo ab exordio scilicet p. Chr. n. saeculi decimi octavi degentis (Kézirat a Magyar Nemzeti Múzeum kézirattárában).

7 Jakab Elek azt állítja, hogy a kolozsvári jezsuita háztörténet Pray Györgyhöz, tőle meg a budapesti egyetemi könyvtárba került (Századok 1889: 6.). Ott azonban nem volt fellelhető. 
diákot tartottak maguk mellett, akik szegény létükre ilyen módon tanulhattak. Ilyen diák-famulusok voltak a tanárok mellett is. Mások mint felszolgálók (servitor, credentiarius) a tanárok, vagy a diákok étkezésénél teljesítettek szolgálatot. Nemosak középiskolások, hanem föiskolai hallgatók is. Évenkint 2-4 ilyen föiskolai hallgató nevével találkozunk a konviktus névsorában. Voltak teljesen ingyen tarott föiskolai hallgatók is. Ezekhez járult a nagyszámú alapítványos növendék: ezek egyes jótevök alapítványának kamataiból éltek. Ilyen módon jelentösszámú diákság jutott ahhoz, hogy olesón tanulhasson.

A föiskolai tanárok száma az előadott tantárgyaktól függött. A bölesészeti karon általában 5 tantárgy szerepelt. 1748-ban például tanára volt a metafizikának, fizikának, logikának, matematikának, etikának. Többször szerepel a ,professor casuum“, a ,professor contraversiarum“. Egy személyben is egyesülhetett e két.feladat elvégzése. ${ }^{8}$

A logikában a fogalomról, ítéletről, az okoskodásról, a módszerröl tanultak. A metafizika anyaga: ontológia (az Ens), aetiológia (okok tana), kozmológia (világ, természet, végzet, stb.), lélektan (benne az angyalokról szóló tan is), a theologia naturalis (Isten és vallás). A matematika anyaga az algebra a másodfokú egyenletekig, geometriából a síkmértan, tömörmértan, kúpszeletek. A fizika (általános, részleges és kísérleti) az egyenes- és görbevonalú mozgások, világrendszer, fénytan, hőtan, az elektromosság, a cseppfolyós testek tanával. Az etika anyaga: az általános erkölestan (az ember természetes állapota, célja, a boldogság), a természetjog a kötelességekröl szóló tannal, a különleges erkölestan a négy sarkalatos erénnyel (okosság, bátorság, önmérséklet, igazságosság), a társasviszonyból eredö tan (családi, polgári, uralkodói, stb.). ${ }^{9}$

A bölcseleti kar élén a dékán állott (decanus philosophiae). Mint dékán azonban, - amint már említettük - nem egymagában képviselte az akadémiát; mellette a középiskolai tanulóknak (a nyelvtani, költészettani, szónoklattani osztályoknak) is volt dékánjuk (decanus linguarum). A két dékán a rektorral együtt alkotta a főiskola magistrátusát. Hozzájuk esatlakozott mint szintén szellemi vezetö a kancellár.

A Collegium Academicum eszerint az intézmény elemi-, közép- és főskolai tagozatának összefogó neve. Az elemi ismeretektól felfelé a teológiával befejezőleg, ez a jezsuita egyetem felépítése.

$\mathrm{Az}$ 1753. évben a föiskola elnevezésében azonban változás állott be. $\mathrm{Ez}$ évben ugyanis az akadémia névhez még az universitas elnevezés is használatba jött. A rektor így írta magát: „Collegii Academici et Almae Universitatis Rector Magnificus". Az ezévi rektor, Gáll András egyben az egyetem kancellárja maradt; ezt a tisztséget ö már régóta viselte. Nagy elfoglaltságában helyettese Patai András procancellarius volt. ${ }^{10}$

Az új elnevezés nyilvánvalóan a főiskola nagyszabású fejlesztésével függött össze. Ugyanis valószínüleg ez évben kezdödött a kollégium új épületének építése. Emellett az egyetem belső fejlesztésének gondolata már erősen forrott. Az állami nevelés egyre jobban népszerüsödö

${ }^{8}$ Leggazdagabb adatokban a kollégiumi Névtár és a konviktorok könyve.

- Fináczy Ernő, i. m. I, 98-100.

10 Kollégiumi Névtár 1753 és a szövegben jelzett években. 
tervében új karok létesítése és új tárgyak bevezetése szerepelt. Az egyetemen néhány évig ugyan még az addigi dékánok maradtak meg, 1768tól kezdive azonban már két dékán: decanus theologiae és decanus philosophiae volt. Ezzel az egyetem formailag tökéletesedett; emellett csakhamar lényeges változások is következtek. 1768-ban 6, a következö évben 9 (köztük 3 világi), 1770-ben 11 teológust (köztük 3 világi) találunk a konviktusban. 1771-ben már 4 negyedéves teológus tanult az egyetemen. Évek folyamán tehát számuk egyre emelkedett.

A tanári kar és az elöadott tantárgyak egyelőre a régi beosztásban maradtak meg. 1753-ban például a dékánon kívül tanára volt a metafizikának, fizikának, logikának, etikának, matematikának, vitatkozástannak. A következö évi beosztás feltüntette, hogy a fizika egyetemes és részleges, és hogy az etika tanára a természetjogot (ius naturale) is tanította. A böleselet tanári kara eszerint a dékánnal együtt 7, a rektorral együtt 8 tagból állott. Közben egy-egy tanár két tárgyat is tanított. 1755-tól kezdve néhány évig a logikusokat. I., a fizikusokat meg II. éves filozófusoknak jelölve találjuk. Az egyetem hallgatóinak száma így alakult: 1753 -ban metafizikus 10 (köztük 3 pap), fizikus 28 (bene 2 pap), logikus 66. 1755-ben másodéves bölesészhallgató 39, elsőéves 57. 1768-ban fizikus 28, logikus 40. A hittudományi kar 9 hallgatóval indult meg. 1772-ben, a jezsuiták müködésének utolsó teljes évében, logikus 36, fizikus 21. A teológusok számát nem jelölték meg, a konviktusban azonban 5 teológus lakott.

Meglepő, hogy az egész kollégium mindennemü tanulóinak száma az akkori kor viszonyaihoz képest milyen nagy volt. Az első években, II. Rákóczi Ferenc szabadságharca idején, a tanulók még kis számban gyülekeztek, de számuk akkor is nött: 1703-ban 50, 1705-ben 90, 1710-ben 104, 1711-ben 186 tanuló nevét olvassuk. A tanév elején elég szép számmal jelentkeztek, de a háború miatt aztán idöközben elszéledtek. Jól jegyzi meg 1706-ban az iskolai Névtár: Miként a tavaszi időben a virágzó fák gazdagsága nem mindíg termékeny ősz bizonyítéka, ugyanúgy a tanév végét sem koronázza az ifjúság sokasága. Utóbb a létszám tetemesen emelkedett: 1712-ben 229, 1747-ben 387, 1753-ban 429, 1771-ben 493. ${ }^{11}$ A nagy szám a jezsuiták munkájának értékelésekor figyelemreméltó. A rend 1579-1773 között, némi megszakításokkal tehát csaknem 200 évig, állott az erdélyi közoktatás szolgálatában.

Munkájának megítéléséhez fontos adat még, hogy a rend a tanitáson kívül egyéb, részben gyakorlati köztevékenységet is fejtett ki. Papírmalmukban többféle papírt állítottak elő, nyomdájuk meg az olcsó könyvkiadást könnyítette meg. E nyomdából sok értékes mü került ki. Gyógyszertáruk diáksegélyzés szempontjából is jelentős, emellett másoknak is rendelkezésére állott. Csillagvizsgálójukban nemesak égitestek megfigyelésével foglalkoztak, hanem a hömérséklet tanulmányozásával, feljegyzésével is.

A tanmenetre és a jezsuita iskolákban szokásos vizsgálatokra nézve a kolozsvári jezsuita háztörténet részletes felvilágosítással szolgál.

11 Kollégiumi Névtár 1753 és a szövegben jelzett években. 
A vitatkozásokra vonatkozólag álljon itt egynéhány adat: 1723-ban az egyetemes történetből vett kérdéseket egy hallgató kitünö eredménnyel védte meg. 1733-ban a bölcseleti vitatkozásban 24 hallgató felelt meg sikerrel, köztük 7 kitünöen. 1746-ban a böleseletből 27 hallgató tett sikeres vizsgálatot. ${ }^{12}$

A rend feloszlatása után három évi átmenet következett, majd 1776-ban a kollégium a piaristák kezelésébe jutott. ${ }^{13}$ Egyidejúleg az egyetemi oktatás is szélesebb alapokra helyezódött. Nemesak a karok száma gyarapodott, hanem a tanszékekben is változás állott be.

A hittudományi kar nem sokáig maradt fenn. Az 1777-78. tanévben voltak még növendékek, de aztán a püspök különböző helyekre osztotta szét öket (Gyulafehérvár, Buda, Bées). 1784-ben II. József kívánságára ugyan valamennyien visszatértek, de két év múlva ugyancsak az ö rendeletére a pesti központi papnevelöbe vonultak. A kolozsvári hittudományi kar ezzel megszünt.

A bölesészeti kart a piarista tanárok látták el. A kar először három tanárból állott (bölcselet, mennyiségtan, fizika), 1778-ban a mennyiségtan két részre oszlott: elméletire és gyakorlatira. Tizennégy évvel késöbb ez utóbbi a fizika-tanár vállára nehezedett. 1779-80-ban a történelem számára új tanszék létesült. I. Ferenc király ezekhez a természettudományi tanszéket füzte.

Mária Terézia királynő 1774-ben az egyetemen jogi kart alapított. A főiskola egyetemi rangját ugyanis a rend feloszlatása után is megtartotta. ${ }^{14} \mathrm{~A}$ jogtudomány tárgyai: római, természet-, büntetöjog, államrendészet, majd 1776-tól a hazai jog. I. Ferenc idejében a tanítás anyaga bővült. Ưj tárgyak lettek: a bánya- és rendörjog, nemzetgazdaság, statisztika, tiszti irály (stilus curalis), mezei gazdaságtan, régi írásmód (paleographia). 1775-ben az orvos-sebészeti tanítás is megkezdődött egy tanárral (sebészet, bonetan, szülészet). I. Ferenc óta szemészetet, állatorvostudományt, majd késöbb patológiát, fiziológiát, orvosi gyakorlatot, vegytant és füvészetet is adtak elő. ${ }^{15} \mathrm{Az}$ orvosképzés sajátos módon állandóan a bölesészeti kar kebelén belïl folyt.

Az egyetemnek ez a szervezete maradt meg 1786-ig. Ekkor II. József az egyetemet akadémiai lyceummá szállította le. ${ }^{16}$ A köztudatban azonban az egyetem elnevezés tovább élt, annál is inkább, mivel a különböző karok továbbra is megmaradtak. A jogi kar 1849-ig működött Kolozsvárt, azután az osztrák-német elnyomatás korában mint jogakadémia Nagyszebenbe került. A böleseleti kart továbbra is a piarista tanárok vezették. Négy tanár a következö tárgyakat tanította: az egyik a meny-

${ }^{12}$ Historia S. J. 1723. 1746.

${ }^{18}$ A piarista alapítóleveleket 1. Erdélyi Károly, A kolozsvári róm. kat. fögimnázium története. $\mathrm{Az}$ 1897-8. évi intézeti Értesítö. 85-9.

${ }^{14}$ Uo. 86, 89.

${ }^{15}$ Vass József, Az erdélyi róm. katolikusok fötanintézete Kolozsvárott. $\mathrm{Az}$ intézet 1856-57. évi Évkönyve. 20-1. - Salzbauer János, A kolozsvári kegyestanító rendi társház és róm. kath. föiskola évszázados történeti vázlata. Intézeti Évkönyv 1876-77-böl. 22-3, 26-7.

10 Jakab Elek, Kolozsvár története III, 428-30. 
nyiségtant (tiszta és alkalmazott $=$ pura et applicata), a második az egyetemes történelmet és nyelvészetet (philologia), a harmadik logikát, metafizikát és etikát, a negyedik elméleti és gyakorlati fizikát. A hallgatók érdeklödését a bölesészek állandó tekintélyes száma mutatta. Nébány adat: 1836-37-ben 210, 1840-41-ben 179, 1844-45-ben 154, 1847-48-ban 161 a bölesészek száma. 1850-ben a reakciós intézkedések nyomán e kar munkája is megakadt. ${ }^{17}$ A piarista tanárok eszerint. hetvennégy évig szolgálták Erdélyben a fooiskolai okłatás ügyét a jezsuitáktól átvett intézmények (egyetem, nevelő intézet, csillagvizsgáló, nyomda) keretében.

\section{2.}

A jezsuiták kolozsvári működésüket 1579-ben a várossal akkor még össze nem épült Kolozsmonostoron, a volt benedekrendi rendházban kezdték meg. E rendház az apátsági templom, mellett, azzal párhuzamosan az északi oldalon, a Szamos felé eső részen állott. Mivel e hely messze esett a várostól, Báthory István alapítólevelének birtokában, 1581-ben benn a városban, a Farkas-utca végén állott ferencrendi rendházban nyitották meg iskolájukat. ${ }^{18}$ Pázmány Péter, a jezsuita rend tanítványa és növendéke e két hely valamelyikén lakhatott. A jezsuiták a farkas-utcai kolostorban 1588-ig, kiutasításukig, illetőleg 1603-ig, újabb távozásukig és egyben ez épület lerombolásáig laktak. A Báthoryegyetemnek eszerint ezek a rendházak voltak első otthonai.

A kiutasított jezsuita tanítók újabb munkavállalását Bethlen Gábor fejedelem engedte meg. 1615-ben az országgyülés a katolikusoknak visszaadta a kolozsmonostori apátsági templomot és ugyanez időkben beljebb, a mostani monostori római katolikus plebániával szemben, Szentpáliné Galambfalvi Borbála asszony, plebánia épületül házat adott. a katolikusoknak. A templomot ettöl fogva a jezsuita lelkészek gondozták, a plebániaházban lakłak, és benne vagyonosabb diákok részére konviktust rendeztek be. Iskolájuk e házzal majdnem szemben, feljebb az apátsági templom felé, állott. Ennek az iskolának udvarán a szegényebb diákok részére otthont, szemináriumot tartottak fenn. Ez az iskola azonban esak alsóbbfokú középiskola volt. ${ }^{19}$

Nagyvárad elfoglalása után, 1660-tól, a török hódoltság szinte Kolozsvár városáig terjedt. A jezsuiták tehát féltek, nehogy tanítványaikat a török elkapdossa és magával vigye. Kérték azért a városi

${ }^{17}$ Familiae clericorum regularium Seolarum piarum Provinciae Hungariae et Transilvaniae. Pro anno 1837-50.

${ }^{18}$ Veress Endre, i. m. I, 137. - A jezsuiták feljegyzése szerint a Farkasutca a ferencrendi templom pátrónusáról, Szent Farkasról kapta nevét (A kolozsvári könyvezö Szủznek históriája. Kolozsvár. Második kiadás 1819-ben, 35 1.)). Ennek azonban ellentmond a kolozsvári városbíró irata, amelyben 1486-ban a ferencrendieknek a templomépítést a Farkasok utcájában (in platea Luporum) megengedi. Jakab Elek, i. m. Oklevéltár, I, 272.

${ }_{19}$ Biró Vencel, A kolozsmonostori belső jezsuita rendház és iskola Bethlen és a Rákóczy fejedelmek idejében: EM. 1981: 117 kk. és kny. Erd. Tud, Füz. 35. sz. 
tanácsot, hogy öket tanítványaikkal együtt engedje be a város várfalai közé. Baresay Ákos fejedelem már 1659-ben intette erre a városbírót és a városi tanácsot. A tanács a felszólításnak végül is engedett. A jezsuiták 1670-ben már benn voltak, „drága pénzeken“ vévén helyet iskolának. ${ }^{20}$

Az elhelyezkedés a Farkas-utca elején azokon a területeken történt, amelyeken ma is a katolikus konviktus (részben piarista rendház) és a gimnázium áll. E területekhez járult még a mai egyetem helyén álló telek; itt a jezsuita atyákon kívül konviktorok is laktak. Az ebédłőt is az utóbbi helyen szerelték föl. ${ }^{21}$

A fejedelemség megszünése után a katolikusok 1693-ban visszakapták az óvári domonkos (ma ferencrendi) zárdát; ezt használatra a jezsuitáknak engedték át.22 Itt folyt az akadémiai tanítás is. 1712-ben még itt találjuk a föiskolát. ${ }^{23}$ Innét azonban rövidesen átvonultak a Farkas-utcába. 1724-ben a jezsuiták az egyetemi diákotthonnak (Báthory-Apor szeminárium) építését azzal a megokolással is szorgalmazták, hogy a távolabbi óvárból kellemetlen a kollégiumba való járás. ${ }^{24}$ Ekkor tehát már a föiskolai oktatás a farkas-utcai épületben folyt. A városnak 1734-böl eredő leírása szerint az akadémiai elöadásokat a nagyszerü iskolaépületben tartották, amely épület a konviktustól keletre esik. ${ }^{25}$ Nyilvánvaló tehát, hogy a mai gimnázium helyén állott épületben folyt a tanítás. A Báthory-szeminárium 1728-ban nyilt meg, ${ }^{26}$ a nemesi konviktus alapítási idejét pedig 1735 -re teszik. Az utóbbi helyen is többször laktak egyetemi hallgatók.

$\mathrm{Az}$ iskolafejlesztés nagyja azonban a külön egyetemi építkezésre esett. A telek, amelyen ma az egyetem épülete áll, szolgált e célra. Az építkezések rendjét egy egyemeletes épületszárny nyitotta meg, amely a templomtól' ${ }^{27}$ (ez 1718-24 között készült el) a Farkas-utca széléig húzódott. A szép ház építése 17C3-ban már folyamatban volt. ${ }^{28}$ 1734-ben a jelzett városleírás már mint kész épületet említi.29

$\mathrm{Az}$ egyetemi föépület a templom folytatásaként a Király-utcában húzódott, a középen egyik szárnya a Farkas-utca felé tért át. Eszerint

${ }^{2}$ Jakab Elek, i. m. II, 812-3; Erd. Orsz. Eml. XV, 95.

${ }^{21}$ Apor Péter, Metamorphosis Transylvaniae: Magy. Tört. Eml. II. oszt. $\mathrm{XI}, 425-33$.

22 Szász Károly, Sylloge Tractatuum 390; Erd. Orsz. Eml. XXI, 148-150.

${ }^{23}$ Jakab Elek, i. m. III, 172.

${ }^{2 *}$ Historia S. J. 1724.

${ }^{2 \pi}$ Descriptio eivitatis Claudiopolis ete. anno D. 1734. Magyar fordításban Vass Józseftöl: Emléklapok Kolozsvár elökorából. Korunk, 1864 és kny. 30. Legújabban Márkos Albert fordította le és adta ki az "Erdélyi Ritkaságok" 18. számaként (Kolozsvár, 1944. Minerva-kiadás). - A jelzett iskola építéséhez 1727-ben fogtak hozzá. Valószínü képét l. Kolozsvár 1798. évi rajzán (Jakab Elek, Kolozsvár története világosító rajzai. XIII. tábla).

. ${ }^{26}$ Biró Vencel, A Báthory-Apor szeminárium története, Kolozsvár, 1935.

${ }^{27}$ Ua., A kolozsvári piarista templom alapítása, Kolozsvár, 1932.

28 Czegei Vass György naplója 361. Magy. Tört. Eml. II, 35.

29 Vass József, Emléklapok Kolozsvár elökorából 30. - Az épület legszebb és teljes alakját l. Az Osztrák-Magyar Monarchia írásban és képben. VII, 111. (Háry Gyula rajza). 
T betü alakot formált. JAKAB ELEK Kolozsvár történetéhez esatolt térképe mutatja az épület elhelyezését és alakját. E tanulmányban közölt térképrészleten a „régi társoda“ az egyemeletes szárnyat, az ,új társoda" a kétemeletes egyetem épületet jelenti.

Ez újabb egyetemi épület keletkezésének ideje még mindíg hozzávetőleges. JAKAB ELEK az építést 1752-1765-ig terjedőnek gondolja. Megjegyzi azonban, hogy még közelebbi kutatás lenne szükséges. ${ }^{30}$

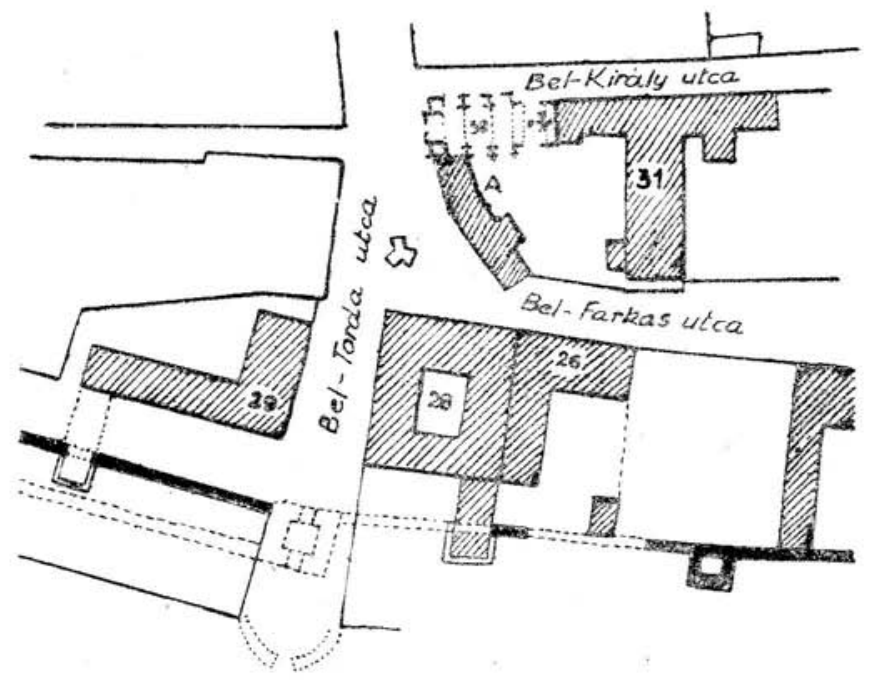

29. Szeminarium

30. Templom

28. Nemes; Konviktus

31. "Uj tarsoda"

26. Gimnázium

A. "Régitarsoda"

Vártol.maradványok

Jezsuita épüle!ek a volt jezsuita,"ma ú. n. piarista templom körmyẻkén Az »új tảrsoda « az egyetem XViII. szazad közepen emeit épiilete

Erre vonatkozó forrásul a jezsuita rendház-történet második kötete kívánkoznék; ez azonban ezidöszerint nem található. Fennmarad még a "Litterae Annuales" címü kéziratos (esetleg nyomtatott) jezsuita egyetemes rendtörténet, de ehhez csak Rómában, esetleg Bécsben lehetne hozzájutni. Ez utóbbi helyen a levéltári anyag óvóhelyre került és már régebben kapott tudósítás szerint a háború tartama alatt nem állhat az érdeklődö rendelkezésére.

A király-utcai rész 1759-ben mindenesetre készen állott, amennyiben Kolozsvár ez évben készült rajzán már jelezve találjuk. De csak jelezve a földszinten és az emeleten három-három ablakkal. ${ }^{31}$

so Jakab Elek, i. m. III, 324-5.

${ }^{31}$ Ua., Világosító rajzok stb. XII. tábla (Szakál János metszete). Mindenesetre az 1734-i városképen még nines rajta. Vö. Borbély Andor, Er- 
E jezsuita kollégium története szempontjából eseményszámba megy, hogy most az egyetemi épület teljes képe, azaz a Farkas-utcáról nézett alakjának mellékelt rajza előkerült. A nagymúltú intézet így közelebb jutott érdeklődésünkhöz. Az épület ugyanis Kolozsvárnak 1835-ben készült tusrajzán tisztán látszik. A rajzoló neve még homályban van, alkotásának idejét azonban a farkas-utcai templom tetejére tett évszám elárulja. A rajznak litografia útján Béesben sokszorosított mása levélpapír-díszuil szolgált, és a papírból egy példány az Erdélyi Múzeum levéltárában fennmaradt. ${ }^{32}$

A rajzoló valahol a feleki oldalon ült, ahonnét a Farkas-utcát jól látta. A Bethlen-bástya, a református templom és kollégium, az úi katolikus gimnázium (elkészült 1821-ben), az egyetem, a kéttornyú jezsuita (most piarista) templom, ennek háta megett a toronynélküli fötéri nagytemplom szemlélhető e képen.

A rajz tanúsága szerint is az egyetem-épület kétemeletes és a kéttornyú templom folytałásaként húzódik, a templomnál kissé ałacsonyabb. Rajta két megtörés látszik. Az elsö megtörés a Farkas-utca felé kiugró szárnyépületet jelenti, három ablakával. A másik kiugrás, ettöł jobbra, a csillagvizsgáló torony. E torony azonban az ú. n. országgyülési terembe feljáró déli oldalhoz ragasztva, 1798-1805 között épült. ${ }^{33}$

$\mathrm{Az}$ egyetem vízszintes tagozódású, párkánnyal díszített barokk épület. Hozzáillett tehát, és szervesen kapesolódott bele az épülettömbbe, ameły körös-körül jezsuita alapítású volt. A két nevelőintézet, a gimnázium, a remek templom, mellette az egyemeletes ház, más oldalról a kétemeletes egyetem, az akkori viszonyok között valamennyi elsőrendủen megépítve és a környezö alacsonyabb házak közül hatalmasan kiemelkedve, tetszetős látványt nyujtottak a szemlélőnek. $\mathrm{Az}$ egészet összefogta a templomtéren álló Szüz Mária-szobor, úgyhogy az egész épületesoport szerves egységbe olvadt.

$\mathrm{Az}$ említett épületeken kiviul, a jezsuita rend tulajdonához tartozott még a kolozsmonostori belsö rendház (amely ma is áll). Ez az iskola beköltözése után a diákság kirándulási, egyben üdülö helyéül szolgált. ${ }^{34}$ Továbbá a rendé volt künn a régi apátsági templom a mellette álló rendházzal.

$\mathrm{Az}$ apátsági templomot azóta is sok csapás érte, mióta a rend visszanyerte. Villámsújtott állapotban volt akkor, amikor azt 1615-ben a. katolikusok megkapták. Somkereki Erdélyi István hozatta rendbe. A templom 1657-ben, a törökdúláskor elégett, csak falai maradtak fenn. Hogy egészen el ne pusztuljon, 1693-ban Perényi Kata asszony, Kemény Zsigmond özvegye, újólag felépíttette. 1704-ben kisebb kuruc

délyi városok képeskönyve 1736-ból: EM. 1943: 197. kk. és Erd. Tud. Füz. 161. sz. 5. kép.

${ }^{32}$ Gedr. bei Joh. Höfelich in Wien. Karácsony János esiesókeresztúri lelkész levele Torma József gondnokhoz, 1841. aug. 13 (Torma-család 1t.). Hálás köszönettel említem meg, hogy e jelentös, sokszorosított tusrajzot Kelemen Lajos találta meg és ő volt szíves rá figyelmeztetni.

${ }^{33}$ Salzbauer János, i. m. 42-3.

${ }^{34}$ Apor Péter, Met. Trans. 433. 


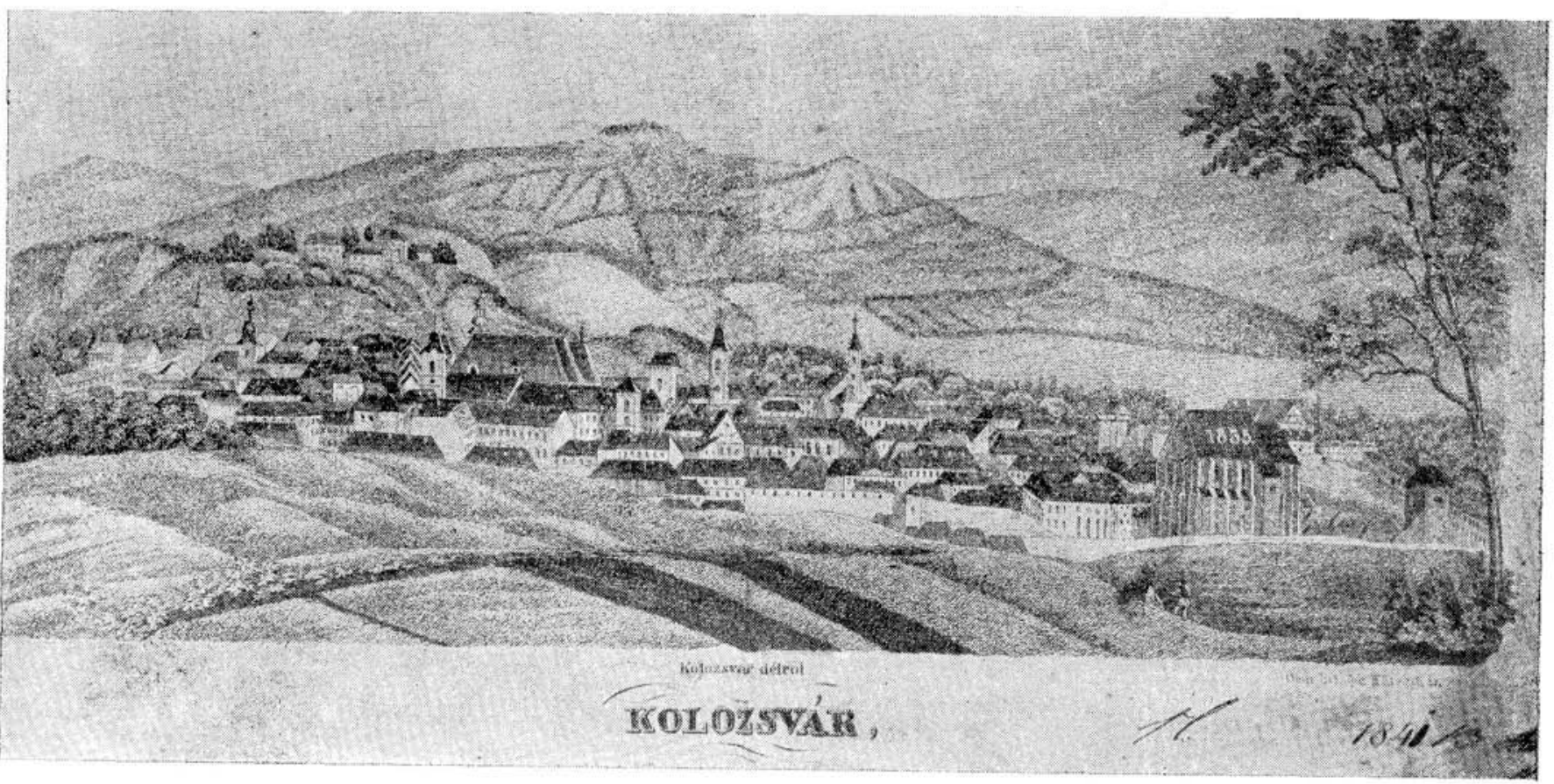

Kolozsvar latkerpe 1835 tajitrol

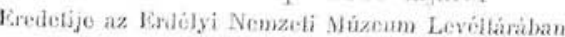


csapat menekült be a templomba, mire az üldöző német katonák gránátot dobtak bele és felgyújtották. ${ }^{35}$ Köveit, a templomot és rendházat körülvevő várfal omladékaival együtt, azután a jezsuiták bennt a városban megkezdett építkezéseikhez használták fel. A templomból a szentély maradt fenn; ez mint kápolna állołt a legújabb korban templommá történt kiegészítésig.

Az apátsági templom mellett állott rendházról a jezsuita rend feloszlatásának évéből, 1773-ból, részletes adatok kerültek elő. E rendházat tudvalevőleg az erdélyi fejedelmek, mivel Kolozsvárt nem volt házuk, a jezsuiták kiutasítása után (1588) lakhelyül használták. Több nevezetesebb esemény füződik e házhoz. Igy Báthory Zsigmond fejedelem bizalmas embereivel itt beszélte meg a törökpárti vezetök kivégzésének tervét. II. Rákóczi György lengyelországi hadjárata elött itt írta alá a szövetség-levelet. A falakra tett felírások szerint az épületet Rákóczi Zsigmond fejedelem (uralkodott 1606-8 között) megnagyobbíttatta, Bethlen Gábor a kinestári javak közül kivéve azt nemesi, azaz magántelekké tette, I. Rákóczi György pedig ezt az intézkedést megerösítette. ${ }^{36}$

A fejedelemség megszünése után a kolozsmonostori birtokot, vele egyetemben e házat a jezsuiták visszanyerték. A rendháznak, vagy mint másként nevezték, Rákóczi-kastélynak, kúriának 1773-ból eredö adatai, legalább az alapformára vonatkozólag, az előző időre is érvényesek.

Eszerint a kúria a teleknek keleti részén állott, homlokzatával Kolozsvár városa felé fordulva. Az elötte húzott fałon két bejárója volt: egy nagyobb és egy kisebb. A nagyobb bejáró íves, rajta három vésett. szobor állott. A középen Szüz Mária ülő alakban, jobbjában a kisded Jézussal, baljában kormánypálea, fején korona. Töle jobbra Szent István királyi palástban, amint a szentkoronát felajánlja. Baloldalt Szent László király áll, vértben, éresisakkal, kardja markolatán rózsafüzérrel.

A portától balra maga a kastély állott. Egyemeletes épület zsindely fedéllel. Tágas, amennyiben a földszinten és az emeleten is tíz-tíz szobára łagozódott. A kúria udvara hosszúságban 21 ölnyire, szélessége pedig 14 ölre (1 kir. öl=2,959 m) terjedt. Ahogy a nemesi kúriáknál szokásban volt, az épület megett itt is kertek (fözelékes, gyümölesös), gazdasági épületek következtek, majd a kovácsok műhelye. Az önellá tást és a jövedelmezöséget szolgálták a különbözö malmok és szeszfözők: serfözö, borégető, liszt-, fürész-, papírmalom, téglavető, ványoló. Földesúri jövedelmi forrás a borárusitás és a húsmérés volt. ${ }^{37}$

${ }^{35}$ Erd. Orsz. Eml. XV, 499. A kolozsvári könyvező Szüznek históriája, 35-6; Vass György naplója 406.

${ }^{30}$ Urbarium, seu conscriptio totalis et integra possessionis Colos Monostra, 1773 dec. 25, Ebben: Residentia seu curia nobilitaris. Erdélyi fiskusi levéltár. XXIII. szekrény a budapesti Orsz. Levt.-ban (Kolozsvári és kolozsmonostori jezsuitákra vonatkozó adatok).

${ }^{37}$ A Rákóczi-kastélyt a fejedelem a rendház omladékaiból építtette (Erd. Orsz. Eml. XV, 499). A közhit szerint az átépítö I. Rákóczi György 
A kétemeletes egyetemi épület további sorsára vonatkozólag kiegészítésül hozzáfüzhetjük még: Pállya István piarista rektor azt konviktorok részére rendezte be, az egyetemi elöadások helyéül meg a mai gimnázium helyén állott iskolaépületet jelölte meg (1777). 1790-ben az erdélyi fökormányszék (gubernium) Nagyszebenből Kolozsvárra költözött és a szükséges helyiségekül a volt egyetemi épületeket foglalta el. A konviktorok elhagyták tehát e helyet, esupán néhány tanár lakott még ott ideiglenesen, 1811-ben e tanárok is véglegesen kiköltöztek ez épületböl. ${ }^{38}$

Mivel a fökormányszék használatába átment egyetemi épületek (a régi- és új „társoda" együtt) idővel romladozni kezdtek és a használatért kapottévi 800 forint bérösszeg a szükséges javításokra sem volt elég, Szepesy Ignác gyulafehérvári püspök 1822-ben az épiulet eladását vette tervbe. $\mathrm{Az}$ ország az épületeket 1829-ben bizonyos kikötésekkel meg is vette. A beiktatás, a vételár teljes átadása után, 1840-ben történt meg. ${ }^{39}$

Azóta ez egyetem-épület az állami egyetem megszervezésekor, 1872-ben jutott újra régi hivatása betöltéséhez. Az új egyetem felállításáig ugyanis elöadó-helyiségül szolgált. Fokozatosan bontották le azt aszerint, amint az új egyetem építése elörehaladt. Először (1893-ban) a keleti szárnyat, majd (1896-ban) a nyugati szárnyat, utoljára a középsö részt bontották le. Az új épület 1902-ben lett kész. ${ }^{40}$

Amikor az új egyetemet felépítették, abba a régi egyetem köveit is beillesztették. $\mathrm{E}$ kövek közül pedig sok a kolozsmonostori apátság Árpád-házi királyok korából származó épületeinek romjaiból került oda. A falakról tehát közel kileneszáz év tekint felénk. Elég idő ahhoz, hogy tisztelettel fejet hajtsunk az ösök közművelődési munkája elött.

fejedelem volt. Ezzel szemben nehézséget támaszt a jezsuiták 1773-ból eredő urbariuma, amely szerint a kúriát Rákóezi Zsigmond nagyobbíttatta. Egykorú adat szerint is a kúria 1648-ban, I. Rákóezi György halála évében már romladozott állapotban volt (... adjacet templo huic eastellum ad septemtrionem, modo quidem ruinosum sed quando nostrorum erat, commode habitabile. Erd. Orsz. Eml. XV, 481).

${ }^{38}$ Salzbauer János, i. m. 9, 16.

U9. 17; Jakab Elek, i. m. III, 834-5.

*o Szabó T. Attila, A Ferene József tudományegyetem épitkezéseinek története. Erdély magyar egyeteme, Kolozsvár, 1941. 247-68 és kny. 


\title{
Erodélyi Tudományos Füzetek
}

\author{
Meginditotta György Lajos
}

Szerkeszti Szabó T. Attila

12. György Lajos: Két dialógus régi magyar irodalmunkban (1 hasonmással) - 2.-

14. Ferenezi Miklós: $\mathrm{Az}$ erdélyi magyar irodalom bibliografiája. 1926. év - 1.50

17. György Lajos: Egy allítólagos Pancsatantra-származék irodaimunkban _ 1.50

20. Szabó T. Altila: Az Erdélyi MúzeumEgylet XVI-XIX. századi kéziratos énekeskōnyvei _ _ _ _ _ _ 1.50

22. Györay Lajos: A francia hellénizmus hullámai az erdélyi magyar szellemi eletben - _ - - - _ _ -

23. Kántor Lajos: $\mathrm{Az}$ Erdélyi MúzeumEgyesưlet problémái

26. Papp Ferene: Gyulai Pál id. Bethlen János gr. körében _ _ _ _ 1.50

28. Biró Vencel: Püspōkjelōlés az erdélyi róm. kath. egyházmegyében _ _ 1.50

31. Ferenezi Miklós: Az erdélyi magyar irodalom bibliografiája. 1929. év -1.50

33. Raika Lászlo: Jókai ,Tōrōkvilág Magyarországon" c. regénye _ _ 1.50

36. Szabó T. Attila: Ax Erdélyi Múzeum Vadadi Hegedũs-kódexe _ _ _ 1.50

37. Kántor Lajos: Hidvégi grół Mikó Imre szózata 1856-ban az Erdélyi Múzeum és az Erdélyi Múzeum-Egyesūlet megalakítása érdekében __ _ _ _ -

2. Kristóf György: Báró Eōtvōs József utazásai Erdélyben Magyar anekdotáink

György Lajos: Magyar anekdotáink
Naszreddin-kapesolatai . Veress Endre: Gróf Kemény Jozsel [1795-1855] (12 keppel) - - -

57. Tavaszy Sándor: A lét és valóság
58. Szabó T. Attila: Adalok Nagyenyed $\mathrm{XVI}-\mathrm{XX}$. századi helyneveinek ismeretéhez (1 térképvázlattal) _ _ _ _

60. Veress Endre: A tōrténetíró Báthory István király (3 képpel) - -

Biró József: A kolozsvári Bánffy-
palota és tervezó mestere. Johann palota és tervezo mestere, Johann 2 .-

65. Janesó Elemér: Az irodalomtōrtênettrás legújabb irányai _. $\ldots \ldots-1.50$

76. Juhász Kálmán: Múveltségi állapotok a Temeskōzben a tōrōk világban _ - 1.20

79. Valentiny Antal: $\mathrm{Az}$ erdélyi magyar irodalom bíbliográfája. 1934. év - 2.

81. György Lajos: Anyanyelvũnk védelme 1.20

82. Grandpierre Edit: A kolozsvári Szent Mihály-templom története ( $34 \mathrm{képpel)} \mathrm{-}$

88. Rass Károly: A mi regényirodalmunk

89. Valentiny Antal: Románia magyar irodalmának bibliografiáa. 1935. év - 1.20

90. Monoki István: Romániában az 1935. évben megjelent román-magyar és magyar idószaki sajtótermékek címjegyzéke _ _ _ - _ _ 2.

92. Janesó Elemér: Nyelv és társadalom 1.50

5. Valentiny Antal: Románia magyar irodalmának bibliográfiája 1936. év - 2.-

96. Kántor Lajos: Czegei grof Wass Ottilia, az Erdélyi Múzeum-Egyesūlet nagy jótevóje (4 képpel) - - - -

So. Lakatos István: A román zene fej16déstōrténete (5 képpel) - $\quad-\ldots 2$ -

100. György Lajos: Dr. Bitay Árpád eletrajzi adatai és tudományos munkássága (1 képpel) _ - - . -

101. Szabó T. Attila: Dés helynevei (2 tér -

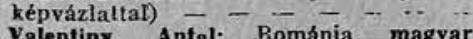
irodalmának bibliografiája. 1937. év 2.-
A z E M k i a dán a

101. Szabó T. Attila: Bábony tōrténete és telepũlése (68 képpel) _-

105. György Lajos: Az "Erdélyi Múzeum" története $(1874-1937) \quad-\ldots-\infty$.

106. Fábián Béla: Nagykend helynevei - 1.-

107. Herepei János és Szabó T. Attila: Levéltári adatok faépitészetũnk tōrté netéhez I. Fatemplomok és haranglábak 2.-

108. Szabó T. Aftila: Levéltári adatok faépitészetünk tôrténetêhez. II. Szếkely. kapuk és fazárak - - - irodalmának bibliografiája. 1938. év -2 .-

114. Szabó T. Attila: A kalotaszegi nagybirtokok jobbágyságának szolgáltatása és adózása (1640-1690)

115. Nagy Géza: Geleji Katona István személyisége levelei alapján $-\frac{1}{\text { Kás }}$ Múzeum-Egyesūlet és az Astra megalakulásában és korai múkōdésében - 1.50

118. Imre Lajos: A kōzmúvelódés mint társadalmi feladat $\quad-\ldots---$

119. Balogh Artúr: A Nemzetek Szỏvetsége húsz Évi mákōdésének mérlege 1.20

120. Györoy Lajos: A magyar nábob _- 1.50

121. K. Sebestyén Jozsef: A Cenk-hegyi Brasovia vár temploma $(11$ képpel) - 1.50

122. Valentiny Antal: Románia magyar irodalmának bibliografíája. 1939. év - 2.-

123. Szabó T. Attila: Ujabb adatok és pótlások kéziratos énekeskönyveink es verses kézirataink kōnyvèszetehez -1.50

124. Ady László: Magyarkapus helynevei (1 lérképvázlattal) _ - _ - -

125. Nyárády E. Gyula: Kolozsvár kōrnyékének mocsárvilága (12 képped és lérképpel)

126. K. Sebestyén Józsel: Régi székely népi eredetú mũemlékeink (20 képpel)

27. Biró Vencel: Gr. Batthyány Ignáe (1741-1798) (1 képpel) - - - - 1.-

129. Ferenczi István: Régészeti megfiğelések a limes dacicus északnyugati szakaszán (12 képpel) - - - -

130. Herepei János: A dési református iskola XVII. és XVIII. századbeli igazgatói és tanitói - - - - - ’ -

132. Tóth Zoltán: lorga Miklós és a szèkelyek román származásának tana $\overline{-}$ 3 Jaḱ́ Zsigmond: Az Erdélyi Nemzeti Mázeum Levéltárának multja és feladatai gési magyarokról - - _ - 2.50

138. Imreh Barna: Mezóbánd helynevei - - 3.-

139. Mikó Imre: A tōrvényhozói ōsszelêrhetetlenség - - - - - -

41. Entz Géza: A dési református templon

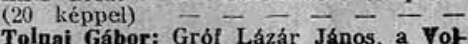
taire-fordító Nagy Géza: Társadalmi ellentétek a régi erdélyi református egyházban - - 1.50

146. Kelemen Lajos: Radnótfája tōrténete 1:-

147. Szabó T. Aftila: Dés telepūlése és lakossága - - - Kórōsi Csoma Sándor lelki alkata és fejlódése (1 képpel) -

. Entz Géza: Szolnok-Doboka kôzépkori múemlékei ( 9 képpel) -

154. Vita Zsigmond: Románia magyar irodalmának bibliográfiája 1910-ben és 1941-ben $-\overrightarrow{-}-\frac{-}{-} \overrightarrow{-}-\overrightarrow{-} \overrightarrow{\text { Jósel }}$ Mike Sándor levelezése $\_\ldots \ldots-2.50$ 
157. Makkai László: $\mathrm{Az}$ erdélyi románok a középkori magyar oklevelekben - - 2-

158. Vita Zsigmond: A Betblen kollégiumi szinjátszás a XVII. és XVIII században - - - - - - - 1.50

159. Palotay Gertrud-Szabó T. Altila: Mezōségi magyar hímzések (137 képpel) - 12. -

161. Borbély Andor: Eirdélyi városok képeskönyve (22 képpel) - - - - 8.-

163. Cs. Bogáts Dénes: Háromszéki oklevélszójegyzek _ _ _ _ - -12 .

165. Ferenczi István: Csíkkarcfalvi régiségek 1.50

166. Herepei János: Scholabeli állapotok Apáczai Kolozsvárra jōvetele elót (4

képpel) - $-\ldots-$

167. Lásżo Gyula: Erdély telepūlestōrténetének vázlata Szent István koráig (4 színes térképvázlaltal) _ _ _ -

168. Nagy Jenō: Lákodalom a kalotaszegi Magyarvalkón _ - $\quad-\ldots$

169. Mozsolies Amália: A magyarországi bronzikor kronológiájáról ___ _ _

170. Vita Zsigmond: A nagyenyedi Bethlenkollégium ifjúságának irodalmi tôrekvései a reform-korszak kezdetén - -

171. Mikees László: A moldvai katolikusok 1640 -47 evi összefrása ( 6 térképvázlattal) - - - - - - - 12.

172. Jakab Antal: Az erdélyi római katolikus pūspōki sték betöltésének vitája a XVII. században _ - _ _ - 2.50

173. Kristól György: Reményik Sándrr - 2.-

174. Makkai Ernô: Sipos Pál és Kazinczy Ferenc

175 Méri István: Középkori temetớnk feltárásmódjáról (8 képpel) - - - 4.-

176. Nagy Jenó: Család-, gúny- és ragadvảnynevek a kalotaszegi Magyarvalkón 2.-
177. Zsakó Gyula: Egy XVIII. századi torockói napló (2 képpel) - $\ldots$ - 2.50

178. Vita Zsigmond: Románia magyar irodalmának bibliográfiája 1912-ben - 2.-

179. Palofay Gertrud: A szolnokdobokai Szék magyar himzései (68 képpel) - 12.-

150. Miárton Gyula: Órdōngôsiüzes helynevei (1 térképvázlattal) - - - - - -

181. Szabó T. Attila-Gaifiy Mót lap Kolozsvár és Gyula: Huszonōt lap Kolozsvár és képlappal) - - - - - -

182. M. Nagy Ottó: Gyarmathi Sámueł élete

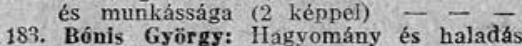
az erdélyi jog fejlsdésében _ - -2 -

184. Venezel Józsei: A volt határórezredek vagyonának sorsa - -

185. Baluzh drtur: Hutiousegi per ors ươyúlési

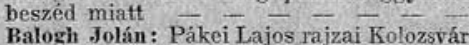
épitészeti emlékeirỏl (31 képpel) _- -

187. Guoth Kálmán: Eszmény és valóság Árpảdkori kirdlylegendäinkban

188. Kováes ignes: A kalotaszegi Ketesd mesekincse

189. Tárkány-Szües Ernö: A juhtartás népi jogszabályai Bálványosváralján - -202.50

190. Mikees Lászl6: Uj erđélvi tudomány - -3.50

191. Buza László : A Szocialista Szovjet Köztársaságok Uniója mint összetett allam

198. Biró Vencel: A kolozsvári jezsuita eovetem szervezete és épitkezései a XVIII. században

193. † Gergely Béla-Szabó T. Attila: A szolnokdobokai Tóki völgy helynevei -10 .

194. Jak6 Zsigmond: Az elpusztult települések

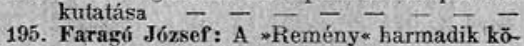
tetének kézirata

50
-
50
-
-
-
-
-
-
-
-50
-
-
-

\section{A felsorolásból kihagyott számok elfogytak.}

\section{AZ ERDĔLYI MÚZEUM-EGYESÜLET JOG-, KöZGAZDASÁG- AS TẢRSADALOMTUDOMÁNYI SZAKOSZTÁLYÃNAK GRTEKEZĒSGI}

1. Csekei István: Tehet-e a kỏzigazgatási intézkedéssel kivételt a miniszter saját rendełete alól? 1.-

2. Buza Lászlo: A kōzjog és a magánjog fogalmi elhatárolásának kérdése. - Vitéz Mioór Gyula:

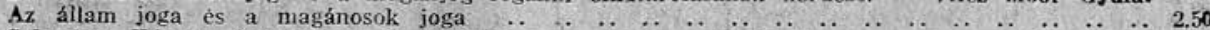

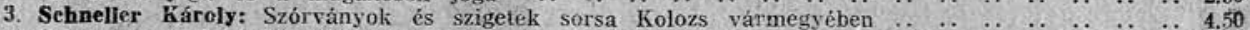

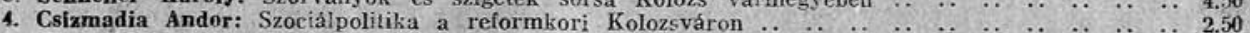

5. Kiss Mór: A római jogi gyakorlatok jelentósége a jogi oktatäsban. — Személyi Kálmán:

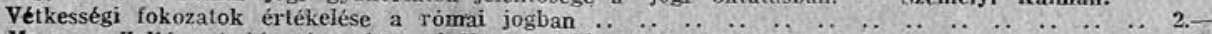

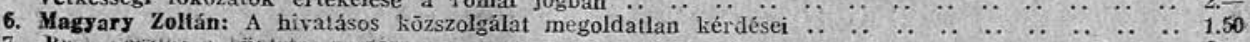

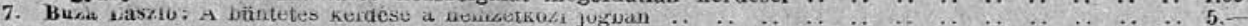

\section{AZ ERDGLYI NEMZETI MUZZUM LEVÉLTÁRÃNAK IKIADVĀNYAI}

Jakó Zsigmond: Az Erdélyi Nemzeti Múzeum Levéltárának multia és feladatai .. .. ..

Jaḱ Zsigmond: Jelentés az Erdélyi Nemzeti Múzeum Levéltảrának 1942. évi mûkō đéséról $\ldots$.. ..

Jałó Zsigmond: Jelentés az Erdélyi Nemzeti Múzeum Levéltárának 1913. évi múkódéséról .. .. 2.-

Jakó Zsigmond-Vàlentiny Antal: A torockószentgyōrgyi Thorotzkay-csalár levéltára (Két oklevéq-

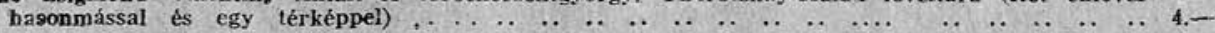

Megrendelhetók az Frdélyi Mámenm kiadóhivatalában

Kolozgvár, Király-uten 14. 